\title{
IN MEMORIAM: FRANK HENRY BRAZIER (1913 - 2004)
}

MARY I. HOUSTON, 863 University Drive, Saskatoon SK, S7N 0J8, and ROBERT W. NERO, 546 Coventry Road, Winnipeg, MB, R3R 1 B6.

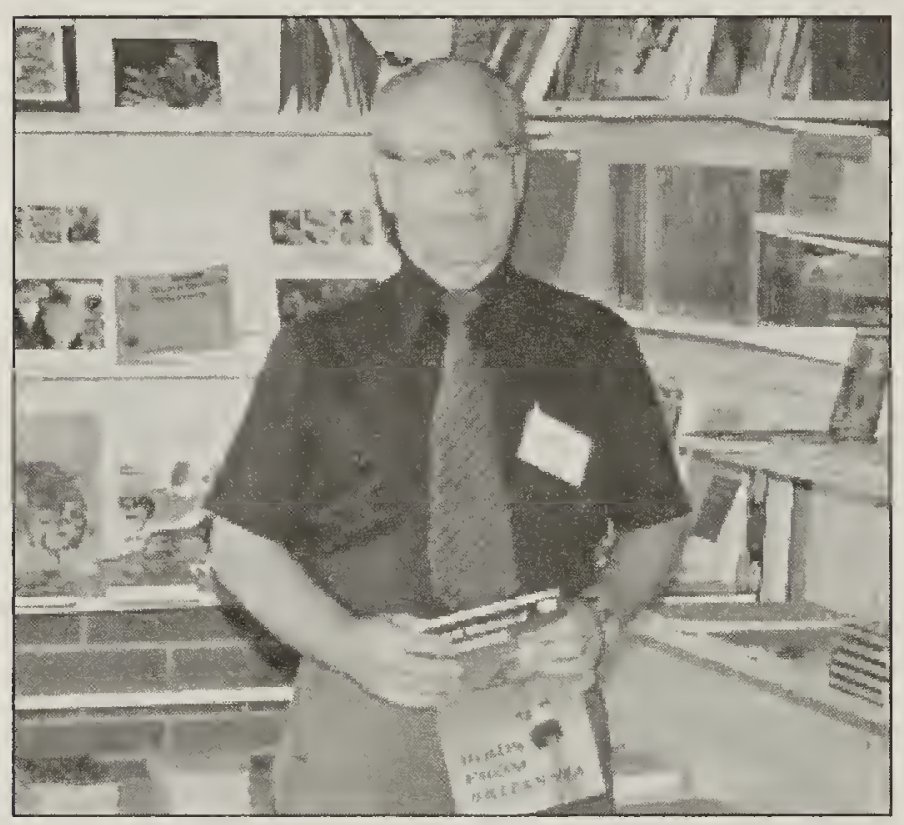

Little is known about Frank's early years. He was born at Macrorie, SK on July 25,1913 and took his schooling in Moose Jaw. After serving overseas with the Canadian Army in World War II, he started work with the Department of Mineral Resources in Regina and lived there for the rest of his life.

He served as president of the Regina Natural History Society from 1954 to 1956 . He began service to the Saskatchewan Natural History Society (SNHS) as chair of the conservation committee in 1956 and immediately after stepping down from the Regina presidency he was elected president of the provincial society. During his year of SNHS presidency, 1956-1957, he called more executive meetings (seven) than any predecessor and helped manage an extremely successful spring meeting in the Cypress Hills. He orchestrated the first successful application to any granting agency; the society received $\$ 1,100$ from the Department of Natural Resources to produce a larger Blue Jay on better quality paper. A generous and admiring Californian, C.M. Goethe, took out twenty 5-year subscriptions to the Blue Jay, one for each University in California, and a 10year subscription for himself. That year, the society printed 5,000 membership pamphlets, 2000 to be distributed by the Saskatchewan Museum of Natural History in its new building, and the rest were distributed widely to previous subscribers, doctors, nature columnists, school unit chairmen and secretaries, school superintendents, officers of the School Trustees Association, Ducks Unlimited "kee-men" and Boy Scout leaders. The result was the largest increase in membership - 600 new members. By 1960, the society had reached an all-time high of 2925 paidup members.

In September 1962, Frank became treasurer of SNHS. It was during this period that he initiated a new venture, a bookshop by mail, the Blue Jay Bookshop. He printed a list of books for sale in the February 1964 Newsletter and mailed out the books as they were ordered. In later years, he circulated a catalogue of books for sale (up to 18 pages of small print) along with issues of the Newsletter. Members of the society obtained a $10 \%$ discount, and Frank would order any book in print on any subject. 
The bookshop showed a profit of $\$ 322$ from book sales in its first full year of operation, increasing to a profit of $\$ 679$ in 1965, \$1290 in 1967 and \$1534 in 1968. As sales increased, the executive realized that Frank should give up his other duties to devote his time to the Blue Jay Bookshop, beginning with the annual meeting in September 1968.

He also took books to meetings where he sold them directly. In 1975, he was invited to take the entire bookshop to the American Ornithologists' Union meeting held in Winnipeg. In 1987, Frank's last year as bookstore manager, there was a record profit of $\$ 5284$ from total sales of $\$ 35,013$. In that year, Frank had taken the bookshop to the SNHS annual meeting, to local society meetings in Regina, Moose Jaw and Saskatoon, to the joint Canadian Nature Federation/SNHS meeting in Saskatoon, a BIOSCAN meeting in Saskatoon and to the Whooping Crane Conservation Association's annual meeting in Regina. Frank handled all this with unusual devotion and exceptional efficiency, as he had done for 19 years. He also stocked books for the three years at the Canadian Wildlife Interpretive Centre beside Highway 1 at Webb. Not only was the bookshop a financial success but the educational impact made by the bookshop was considerable. At the end of 1987, Carol Bjorklund suceeded Frank as bookstore manager.

The prestigious Conservation Award of the SNHS was presented to Frank in 1969 in recognition of his long service to the Society in various offices, and his enterprising and creative management of the bookshop. In 1987 a new class of honorary members, known as Fellows, was created. Appropriately, Frank was among the first four awardees. At the same time, he was named Honorary President of the Society for a five- year term. Frank went the "second mile" in service to the naturalist community and he was generous with both time and money.

On occasion he gave back part of his honourarium $(25 \%$ of the bookstore profits) to the Society and in June 1983, he donated sufficient money to cover the cost of a colour front cover of the Blue Jay: an outstanding photograph of a Swamp Pink, Arethusa bulbosa, taken by his close friend and birding companion, Elmer Fox.

For years, Frank summarized Regina bird records for each season for the regional editor of Audubon Field Notes. He also contributed 52 items to Blue Jay, including six book reviews and notes on a cougar and an unusual mushroom in Regina, and edited three issues of the Newsletter when the incumbent editor, Doug Wade, took up a new position at the Northern Illinois University.

A keen birder with a flair for differences in plumage or behavior that might signal the presence of an unexpected species, Frank took delight in sharing his observations of unusual species, including the first confirmed Saskatchewan records of the Ruff (May 8, 1965); Black-throated Gray Warbler (May 3, 1965); and Blue-winged Warbler (November 9, 1965). The first provincial sighting of the Yellow-crowned Night Heron (20 May 1978, with Callin and Chaskavich) was near Lebret. The Yellow-billed Cuckoo sighted on July 6, 1987 was also seen by Bob Kreba.

His firsts for the Regina area were the Chimney Swift (May 14, 1958, with E.L. Fox); Caspian Tern (July 22-23, 1960, with E.L. Fox); and Harlequin Duck (September 6, 1958). With Elmer Fox and Fred Lahrman, Frank reported Regina's first breeding records of the 
Western Grebe and Forster's Tern (June 18, 1960), and Yellow-rumped Warbler (July 8-12,1965).

He also had a number of hypothetical first records. Probably reliable firsts for Regina were Kentucky Warbler (heard only, on July 14, 1989); Ivory Gull (September 4, 1989); Laughing Gull (May $19 \& 26,1959$ ), and for the province were Least Tern (May 26, 1957); Golden-winged Warbler (May 18, 1962) and Lesser Black-backed Gull (May 28, 1977).

Several times each year, Frank and his wife, Marjie, would go to the Qu'Appelle Valley, anywhere from Fort Qu'Appelle to beyond Broadview, for a day of intensive birding with Frank's close friend, Manley Callin. Their close ties are evident in Frank's memorial to Callin (Blue Jay 44:66-69, June 1986).

When his beloved Marjie died on November 13, 1990, Frank was bereft. For an intimate glimpse of this man, see the photograph and in memoriam, "Rosy Finch in Regina - Marjie's last bird" (Blue Jay 49:40-41, March 1991). Although he continued his daily walks around Wascana Lake for several years after his wife's death, he gradually lost interest in life. He died in the Wascana Rehabilitation Centre at 91 years of age, on September 6, 2004. Frank was one of the most innovative, dedicated and industrious members of the Society since its inception in 1949.

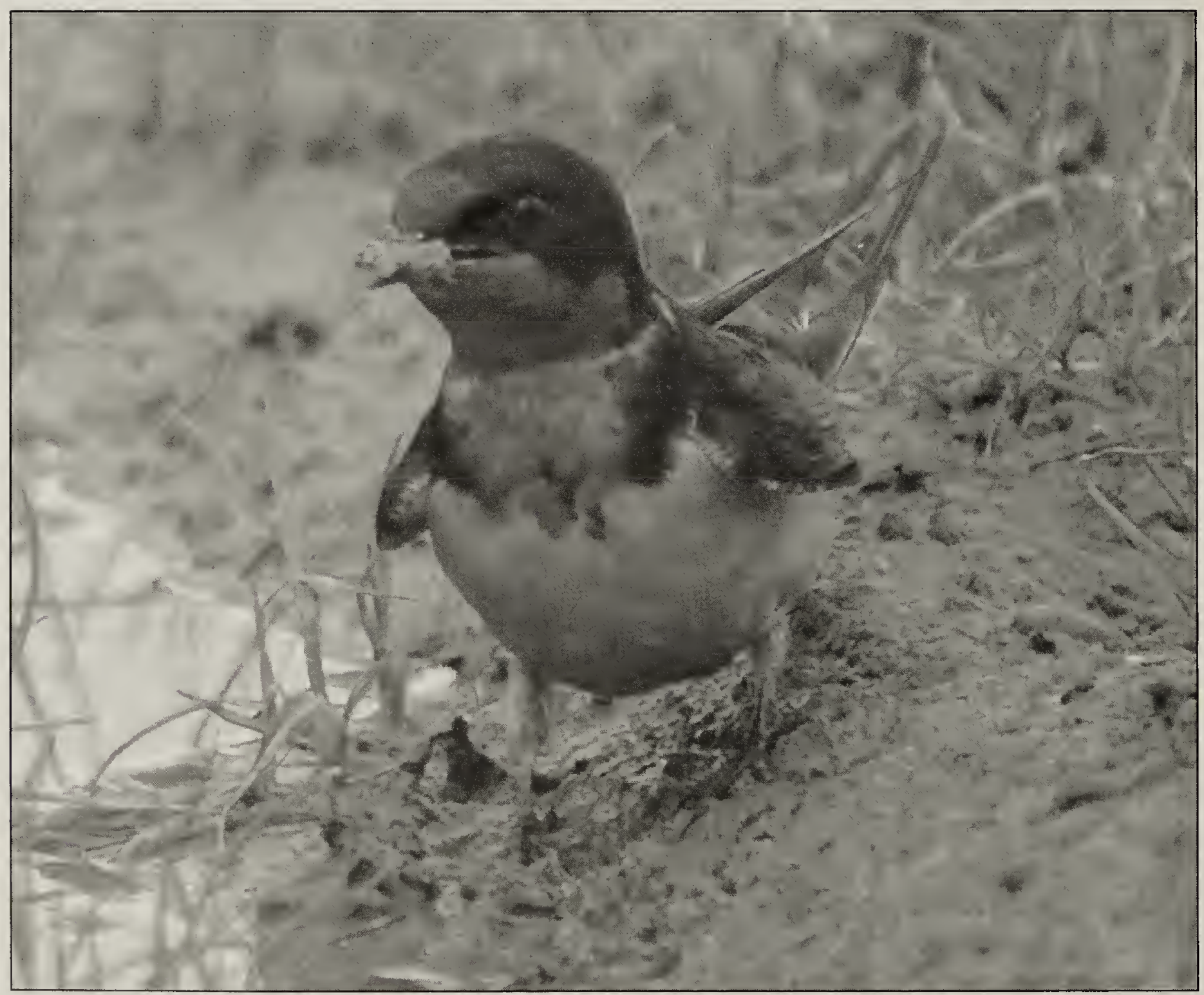

